Syntax Fusion : Jurnal Nasional Indonesia

p-ISSN: -

e-ISSN : 2775-4440

Vol. 1, No. 7, Juli 2021

\title{
ANALISIS TAURAT SEBAGAI HUKUM ALLAH DAN HUBUNGANNYA DENGAN KEHIDUPAN UMAT ALLAH DALAM PERJANJIAN BARU
}

\author{
Djone Georges Nicolas \\ STT IKAT Jakarta - Pascasarjana \\ Email: djonealexandrenathanael@gmail.com
}

\begin{abstract}
Abstrak
Kesalahpahaman atau kurang pengertian mengenai makna Taurat sebagai hukum Allah menjadi suatu problem tersendiri dalam kehidupan umat Allah dari zaman ke zaman. Tujuan penulisan ini hendak mengetahui apa hubungan umat Allah di dalam Perjanjian Lama, dalam hal ini bangsa Israel dengan umat percaya di dalam Kristus Yesus di dalam Perjanjian Baru berkaitan dengan Taurat? Penulisan ini menggunakan pendekatan kualitif dengan metode deskriptif dan analisa literatur maupun literatur research. Teknik pengumpulan data melalui Alkitab, sumber buku-buku, artikel digital, jurnal-jurnal, serta dokumen lain yang berkaitan dengan masalah yang menjadi objek kajian. Melalui pemahaman yang benar tentang Taurat, ditemukan bahwa terdapat hubungan perjanjian Allah dengan umat-Nya baik di dalam Perjanjian Lama maupun dalam Perjanjian Baru berkaitan dengan keselamatan di mana penggenapan-nya ada di dalam pribadi Yesus Kristus. Kesimpulan, Taurat yang merupakan hukum Allah bagi manusia tidak merupakan sumber pembenaran bagi manusia yang sudah rusak karena kejatuhan di dalam dosa, melainkan Taurat hanyalah bayangan dan penuntun kepada sumber pembenaran yang sesungguhnya dan yang telah dinubuatkan sebagai penggenap atas hukum Taurat: yaitu Yesus Kristus Tuhan Sang Mesias dan Sang Iman Besar Agung yang telah menyempurnakan hukum Tuhan melalui pengorbanan-Nya, dan telah mewujudkannya di dalam suatu Perjanjian yang Baru yang tidak lain adalah Perjanjian Kasih, dimana pembenaran dan keselamatan tersedia hanya oleh anugerah di dalam iman kepada Yesus Kristus sendiri.
\end{abstract}

Kata Kunci: Hukum Allah, Kehidupan Umat Allah, Perjanjian Baru.

\section{Pendahuluan}

Berbicara Taurat selalu dan pasti dikaitkan dengan Bangsa Israel dalam Perjanjan Lama hingga hari ini, sebab kehidupan bangsa Israel dibangun atas dasar hukum-hukum Allah, oleh karena Allahlah yang telah memilih dan menetapkan mereka sebagai bangsa yang kudus, yang khusus dan berbeda dari bangsa-bangsa lain. Maka, Allah juga memberi 
bagi mereka melalui perantaraan Musa hukum-hukum yang mengatur kehidupan mereka sebagai umat-Nya agar mereka hidup dalam kehendak-Nya. Namun, Hukum Taurat yang merupakan satu topik utama dalam kepercayaan bangsa Israel sering menjadi kontroversi di kalangan umat percaya atau Kristen hingga masa kini.

Sepuluh Perintah Tuhan yang terdapat di dalam Kitab Keluaran 20:3-17 adalah suatu pedoman yang masih relevan dari waktu ke waktu, sebab di dalamnya terkandung pola-pola hubungan yang selaras dengan eksistensi manusia yang berasal dari perbedaan budaya maupun peradaban dalam cara berinteraksi dengan Tuhan, dengan sesama maupun dengan pribadinya sendiri (Christie Kusnandar, 2017). Cara menerapkan Taurat pada zaman Yesus mengakibatkan pemahaman yang terwujud dalam tindakan menjadi berbeda dengan apa yang Yesus maksudkan, oleh karena dalam kitab Injil beberapa kali ditemukan silang pendapat di antara kaum-kaum Yahudi yang menekuni Taurat dan Yesus (Lina Sri, 2020). Menurut (Iman dan Ong, 2020), Hukum Taurat dimengerti sebagai suatu ungkapan dari karakter kehidupan di dalam konteks perjanjian, oleh karenanya dikenal sebagai ekspresi perjanjian, dengan demikian bisa dipahami bahwa inti yang dikandung hukum taurat atau maknanya yang sakral berkaitan dengan perjanjian.

Terdapat dalam kalangan-kalangan Kristen di masa kini, sebagian yang mengadopsi budaya Yahudi dalam menjalankan ritual keagamaan, dan di sisi lain, sebagian yang menolak pengabungan tersebut dan memandang Taurat dan budaya Yahudi sebagai suatu kekhususan bagi bangsa Israel di dalam Perjanjian Lama, sehingga tidak perlu dihubungkan dengan Kekristenan di masa Perjanjian Baru. Tujuan penulisan ini hendak mengetahui apa hubungan umat Allah di dalam Perjanjian Lama, dalam hal ini bangsa Israel dengan umat percaya di dalam Kristus Yesus di dalam Perjanjian Baru berkaitan dengan Taurat? Melalui pemahaman yang benar tentang Taurat, ditemukan bahwa terdapat hubungan perjanjian Allah dengan umat-Nya baik di dalam Perjanjian Lama maupun dalam Perjanjian Baru berkaitan dengan keselamatan di mana penggenapan-nya ada di dalam pribadi Yesus Kristus.

\section{Metode Penelitian}

Penelitian ini menggunakan metode kualitatif deskriptif dan analisa pustaka dan tafsir narasi, dengan tujuan menganalisis dasar kontraproduktifitas perdebatanperdebatan teologis para hamba Tuhan di Youtube sejak pandemi Covid-19 di Indonesia. Pengumpulan data dilakukan melalui berbagai sumber: Alkitab, buku-buku, jurnal-jurnal, artikel digital, dan dokumen lain yang berkaitan dengan masalah yang dikaji. Penelitian kualitatif menurut Bodgan dan Biklen (Anggito \& Setiawan, 2018) adalah suatu prosedur penelitian yang menghasilkan tipe data deskriptif berupa ucapan atau tulisan maupun perilaku orang-orang yang diamati di dalam suatu konteks dan dikaji dari sudut pandang yang lengkap dan komprehensif, maupun menyeluruh atau holistik. 


\section{Hasil dan Pembahasan}

\section{Pemahaman Hulum Taurat}

Istilah "Taurat" yang dalam bahasa Ibrani disebut "Torah" yang familiar dikenal sebagai Kitab-kitab Musa (Pentateukh) atau kelima Kitab pertama yang tertulis di dalam Alkitab, merupakan hukum Allah yang bersifat perintah-perintah dan juga pengajaran dari Allah bagi umat-Nya yang diamalkan dalam 10 Hukum (Kel. 20:1-17), kemudian seluruh hukum dan peraturan-peraturan yang ditetapkan Tuhan, sehingga Taurat digambarkan sebagai Undang-undang Dasar bagi bangsa Israel. Hal ini senada dengan David L. Baker yang mendefinisikan Taurat sebagai hukum dan pengajaran yang dapat diberi tema utama sebagai "janji Allah kepada nenek moyang Israel sedang digenapi" (David L. Baker, 2013). Bagi Donald Guthrie, Hukum Taurat adalah gambaran dari semua landasan hidup agama orang Israel menurut Perjanjian Lama (Donald G., 2019). Menurut J.W. Wehnam Hukum Taurat merupakan pengajaran maupun keputusan yang ditetapkan bagi suatu kasus khusus dan juga secara makna lebih luas juga dapat diartikan sebagai semua kumpulan peraturan yang menata hubungan Tuhan dengan manusia dan juga hubungan manusia dengan sesamanya (Wehman, t.th). Menurut Watchma Nee, hukum Taurat mempunyai fungsi yang positif di dalam tangan Allah, namun hukum Taurat menjadi seperti pengasuh dan wali umat pilihan Allah dengan tujuan membawa mereka kepada anugerah di dalam Kristus (Watchma Nee, 2020). Maka berkaitan dengan rencana mulia Allah, (Witness Lee, 2020) menyampaikan bahwa Ekonomi Allah dan hukum Taurat Allah dalam ekonomi-Nya, serta anugerah Allah dalam ekonomi-Nya ketiganya merupakan pokok pembahasan seluruh isi Alkitab dari Kitab Kejadian 1 hingga pasal terakhir Kitab Wahyu.

Jadi Hukum Taurat merupakan ketetapan atau perintah Allah sebagai penuntun bagi bangsa Israel yang berhubungan dengan rencana pengenapan janjiNya bagi mereka dan bagi semua bangsa kemudian. Dengan kata lain, Taurat mempunyai hubungan erat dengan Perjanjian Baru. Hukum Taurat yang merupakan hukum yang tertulis mengalami perkembangan dengan adanya juga tradisi lisan, sebab tradisi lisan bersumber dari Hukum Taurat. Menurut Simanjuntak Cyrellus, hukum orang Yahudi berjumlah 613 yang berkembang hingga tahun $200 \mathrm{M}$ menjadi ribuan sehingga tambahan itu dituliskan dalam kitab Misnah dan terkumpul di dalam Talmud Yahudi pada tahun 400 M (Cyrellus, 2008). H.L Senduk memaparkan ikhtisar dari seluruhan hukum Musa diantaranya: Hukum Umum, Hukum Sipil, Hukum Pidana, Hukum Pajak, Hukum Perang, Hukum Makanan, Hukum Hari Raya, Hukum Penyucian, Hukum Imamat dan Hukum Korban atau persembahan (H.L. Senduk, 2014).

\section{Hubungam Taurat dan Perjanjian Baru}

Taurat dalam Perjanjian Lama adalah suatu perjanjian yang mempunyai batas waktu tertentu, sebab dicatat oleh Injil bahwa "Hukum Taurat dan kitab para nabi berlaku sampai kepada zaman Yohanes ...” (Luk. 16:16). Hukum Taurat tidak mungkin menyempurnakan manusia, sebab darah binatang tidak dapat menghapuskan dosa manusia, maka hukum-hukum Musa merupakan bayangan dari keselamatan yang akan 
digenapi di dalam Perjanjian Baru di dalam Yesus Kristus dan yang terus dinantikan oleh bangsa Israel. Terdapat kesaksian eksistensi Yesus dan hubungannya dengan hukum Taurat di dalam Perjanjian Baru khususnya dalam Injil-Injil sinoptik, yang dengan jelas dan gamblang menyatakan bahwa Yesus datang untuk menggenapi Hukum Taurat. Yesus sendiri berkata: "Janganlah menyangka, bahwa Aku datang untuk meniadakan hukum Taurat atau kitab para nabi. Aku datang bukan untuk meniadakannya, melainkan untuk menggenapinya" (Mat. 5:17). Yesus sebagai manusia dan keturunan Yahudi berada di bawah otoritas hukum Taurat dan berhasih mentaatinya sekaligus menggenapinya, terbukti Ia satu-satunya manusia yang sama sekali tidak berbuat dosa. Cara melakukannya adalah dengan disalib dan mati, sebab dengan demikian Ia telah memenuhi semua tuntutan hukum Taurat terhadap umat Allah, sebab dasar hukum Taurat adalah perbuatan baik yang membawa kepada hidup (Gal. 3:12).

Melalui kematiannya sebagai manusia, hukum Taurat yang merupakan perintah dan ketentuan dibatalkan sehingga tidak lagi berkuasa atas manusia yang masuk dalam Perjanjian Baru di dalam Kristus Yesus, sebab Yesus adalah penggenapan dari Perjanjian Lama dan awal dari suatu Perjanjian Baru, yaitu Perjanjian Kasih yang meliputi Hukum Kasih. Abraham Park menyampaikan berhubungan dengan Perjanjian Lama dan hukum Taurat, bahwa Yesus Kristus merupakan Iman Besar yang sempurna dari Perjanjian yang Baru, sebab Bait Suci yang berbentuk kemah yang dibangun melalui Musa dan imam besar dari garis keturunan Lewi yang melayani tidak sempurna hanya merupakan bayangan yang telah digenapi dalam kesempurnaan-Nya oleh Kristus sebagai Imam Besar di Sorga sebagai Bait yang sesungguhnya (Abraham Park, 2017). Demikianlah, Yesus menjadi Anak Domba Allah yang mencurahkan darah penebusan mengantikan darah anak domba binatang, sekaligus Iman Besar Agung.

\section{Pelaksanaan Taurat Kini (Iman dan Kehidupan)}

Menurut Warren W. Wiersbe, hukum Taurat tidak boleh dibatalkan (Warren W., 2012). Jelas yang dibatalkan adalah tuntutan hukum Taurat dan bukan hukum Taurat itu sendiri, Dengan demikian dasar hukum di dalam Perjanjian Baru dalam pelaksanaannya adalah hukum kasih diawali dari Yesus Kristus yang menunjukkan kasih-Nya melalui kehidupan dan pelayanan-Nya selama di bumi, hingga pengorbanan-Nya di kayu salib. Hukum kasih berbeda dengan hukum Taurat dalam Perpanjian Lama yang menuntut orang Israel pada ketaatan mutlak dan sepenuhnya akan hukum untuk memperoleh janji hidup dan keselamatan, orang-orang yang mempercayai Yesus Kristus Sang penggenap hukum Taurat dan fondasi dari Perjanjian Baru, tidak dituntut tunduk dan melaksanakan hukum Taurat, melainkan mempraktekkan ajaran Kristus yang adalah prinsip hukum Taurat yang telah disempurnakan di dalam kasih, yang meliputi kasih kepada Tuhan dan kepada sesama di dalam iman yang merupakan kasih karunia Allah. Maka Paulus dengan tegas berkata: "Kamu lepas dari kasih Kristus, jkalau kamu mengharapkan kebeneran oleh hukum Taurat; kamu hidup di luar kasih karunia. Sebab oleh Roh, dan karena iman, kita menantikan kebenaran yang kita harapkan. Sebab bagi orang-orang yang ada di 
dalam Kristus Yesus hal bersunat atau tidak bersunat tidak mempunyai sesuatu arti, hanya iman yang bekerja oleh kasih" (Gal. 5:4-6).

Watchma Nee menulis bahwa merupakan tuntutan Allah terhadap daging manusia yang ada di dalam Adam dan sudah rusak, sehingga Allah menghendaki manusia tidak menaruh harapan apapun pada dirinya sendiri lagi, melainkan melalui kematian terhadap hukum Taurat di dalam Kristus Yesus manusia terlepas du tuntutannya (Watchma Nee, 2020). H.L Senduk berkata bahwa terdapat keselamatan yang sempurna bagi tubuh, jiwa dan roh di dalam Kristus bagi semua orang, karena di dalam- Dia telah tersedia pembenaran, pencucian dan pengalaman hidup baru (H.L. Senduk, 2014). Dapat dikatakan bahwa tekanan hukum Taurat dalam Perjanjian Lama mengenai tuntutan Allah, namun di dalam Perjanjian Baru, penekanannya ada pada anugerah Allah melalui iman di dalam Kristus Yesus. Walaupun perlu diakui bahwa banyak gereja masih menganggap bahwa praktek hukum Taurat tetap harus dilaksakan sepenuhnya seperti di dalam Perjanjian Lama dengan praktek Sabat yang tetap ditekankan harus dilaksanakan pada hari Sabtu dan bukan di hari Minggu, tetapi inkonsisten dalam hal mempersembahkan korban darah binatang khususnya anak domba sebagai salah satu contohnya.

\section{Taurat dan Sabat}

Sabat merupakan salah satu perintah dari sepuluh hukum yang ditulis oleh Allah sendiri di dua loh batu dan diserahkan kepada Musa sebagai kewajiban bagi umat Israel. Sabat diartikan sebagai perhentian dan merupakan hari khusus dan kudus bagi Allah dimana tidak boleh melakukan kegiatan pekerjaan apapun (Kel. 20:8-11). Hari Sabat adalah suatu tanda perjanjian antara Allah dan Israel yang menunjukkan hubungan khusus Israel dengan Allah. Dalam peristiwa penciptaan, pun, Allah telah istirahat pada hari ketujuh. Menurut H.L. Senduk, terdapat beberapa hari Sabat: Hari Sabat Hari yang ketujuh, Bulan Sabat pada permulaan dari tiap bulan dimana umat membawa korban khusus (Bil. 28:9-15; Im. 23:23-32), Tahun Sabat atau setiap tahun ketujuh berkaitan dengan tanah, Tahun Sabat Yobel setelah 7 Tahun Sabat $(7 \times 7=49$ Tahun) tahun ke-50 (Im. 25:8-55) yang disebut hari hari Besar Grafirat atau pendamaian (H.L. Senduk, 2014). Hari Sabat menjadi hari Ibadah bagi orang Israel, hari Tuhan maupun hari sukacita (Hos.2:10; Yes. 56:6-7). Menurut Xavier Leon-Dufour, hari Sabat mulai dihitung hari Jumat setelah matahari terbenam sampai Sabtu petang (Xavier L., 1990).

Hari Sabat di sisi lain merupakan pengingat bagi umat Israel bahwa sebelumnya merekan berstatus budak di Mesir yang telah dibebaskan Allah dengan tangannya yang perkasa (Ul. 5:15), tetapi di Perjanjian Baru Yesus adalah Tuhan atas Hari Sabat (Luk. 6:5) sehingga perhentian yang sesungguhnya terletak pada Sabat Eskatologis yang sudah menjadi bagian orang percaya di dalam iman kepada Kristus Yesus, yaitu hidup yang kekal (Wahyu 14:13).

\section{Taurat dan Hubungan dengan Sesama}

Taurat dipandang dari Sepuluh Hukum yang diberikan Tuhan kepada Musa di puncak gunung Sinai dapat dikelompokkan menjadi dua pokok pembahasan, yakni kasih 
manusia terhadap Allah (Kel. 20:2-11) dan kasih manusia terhadap sesamanya (Kel. 20:12-17). Hal itu diteguhkan oleh yang disampaikan Tuhan Yesus ketika Ia ditanyakan tentang hukum yang terutama dalam hukum Taurat dengan berkata: "Kasihlah Tuhan, Allahmu... itulah hukum yang terutama dan yang pertama. Dan hukum yang kedua, yang sama dengan itu, ialah: kasihlah semamu manusia seperti dirimu sendiri (Mat. 22:35-39). Dengan kata lain, Yesus menegaskan bahwa kasih akan Allah dibuktikan dan diimplementasikan melalui kasih terhadap sesama sehingga di dalamnya genaplah seluruh isi hukum Taurat (Mat. 22:40).

Menurut Nur Fitriyana, pernyataan di atas memberi petunjuk bahwa pandangan Yesus tentang Kerajaan Allah bukan sekedar melibatkan pengeseran revolusioner terhadap kerajaan-kerajaan duniawi, tetapi juga memberi wawasan rohani tentang kerinduan yang paling Allah inginkan dari manusia, sebab manusia saling membutuhkan sehingga tidak mungkin menjadi lengkap tanpa yang lain (Nur F., 2017). Kasih kepada manusia menurut urutan hukum Taurat di awali pertama dengan perintah memberi hormat kepada orang tua dengan janji umur panjang (Kel. 20:12). Hubungan keluarga merupakan gambaran relasi yang paling dasar dimana kasih yang murni dibagikan satu dengan yang lain, baik dari orang tua kepada anak-anak, dan sebaliknya dari anak-anak kepada orang tua, seperti hubungan Bapa Sorgawi dengan anak-anakNya di dalam Kristus Yesus. Perjanjian Baru mengungkapkan bahwa yang dimaksud dengan keturunan Abraham bukanl mereka yang dilahirkan secara fisik, tetapi mereka yang telah dipersatukan dengan Kristus dan menjadi milik-Nya. Dan Perjanjian tersebut mengandung komitmen Allah yang telah mengikat pribadiNya sendiri dengan umatNya dengan tujuan menjadi Bapa bagi mereka dan dengan demikian menjadikan mereka anak-anak-Nya, keturunan-Nya. Ini merupakan suatu perjanjian keluarga sehingga orang percaya mempunyai keberanian karena iman kepada Kristus memanggil Allah sebagai Bapa menurut Warisman Harefa (Harefa W., 2014).

Perintah Taurat yang kedua berhubungan dengan manusia adalah larangan untuk membunuh (Kel. 20:13). Tentu membunuh berkaitan dengan nyawa manusia yang menjadi hak dan milik Tuhan, tetapi juga di dalam Perjanjian Baru dapat dihubungan dengan pembunuhan karakter, pembunuhan iman dan sebagainya seperti contoh yang diberikan oleh Rasul Yohanes dengan berkata bahwa manusia yang membenci saudaranya, dengan kata lain tidak mengasihi saudaranya merupakan pembunuh (1 Yoh. 3:15). Berkata bahwa kuasa rohani yang tidak disertai kasih merupakan hal yang sangat berbahaya (Craig S., 2015). Kemudian, perintah Taurat yang ketiga berhungan dengan larangan untuk berzinah (Kel. 20:14) yang berhubungan dengan tanggung jawab kesatuan, kesetianan dan kesucian hidup di dalam hubungan keluarga, dalam hal ini suami dan istri, sama seperti Yesus Kristus Tuhan setia terhadap mempelaiNya yang adalah gerejaNya. Di dalam Kristus dalam Perjanjian Baru, tubuh orang percaya adalah Bait Allah dimana Roh Kudus tinggal sehingga tidak boleh dicemarkan. Berzinah dapat terjadi bukan saja melalui perbuatan tidak terpuji, tetapi juga dalam hati melalui niat yang tidak kudus (Mat. 5:28). 
Perintah hukum Taurat yang kempat berhungan dengan kasih manusia terhadap sesama adalah larangan untuk mencuri (Kel. 20:15) yang menurut Kiswara menyangkut makna sosial dari kepunyaan atau kepemilikan seseorang (Kiswara, 1992). Tentunya orang yang dipenuhi dengan kasih Kristus dan juga mengasihi sesama tidak mungkin mau merugikannya, sebab mengasihi adalah berkorban dan bukan merampas hak orang lain. Dan perintah selanjutnya hukum Taurat yang berhungan dengan kasih manusia terhadap sesamanya adalah larangan untuk bersaksi dusta (Kel. 20:16) yang dapat berbicara tentang menjaga nama baik sesama manusia karena kasih, karenakan di dalam Kristus dan oleh kuasa Roh Kudus kita menjadi saksiNya Kristus, dan saksi Kristus otomatis menyaksikan tentang kebenaran dimana berada dan kapan pun waktunya (Kis. 1:8). Dan perintah yang terakhir hukum Taurat berhubungan dengan kasih manusia terhadap sesamanya adalah larangan untuk mengingini apapun yang menjadi milik sesama (Kel. 20:17) yang mempunyai sifat egois dan mungkin iri hati sehingga tidak mendatangkan kebaikan bagi semua orang.

\section{Kesimpulan}

Taurat yang merupakan hukum Allah bagi manusia, khususnya bagi orang Israel di dalam Perjanjian Lama adalah baik. Namum, hukum Taurat tidak merupakan sumber pembenaran bagi manusia yang sudah rusak karena kejatuhan di dalam dosa, baik bagi bangsa Israel sebagai bangsa pilihan maupun bangsa lain, melainkan Taurat merupakan bayangan dan penuntun kepada sumber pembenaran yang sesungguhnya dan yang telah dinubuatkan sebagai penggenap atas hukum Taurat: yaitu Yesus Kristus Tuhan Sang Mesias dan Sang Iman Besar Agung, yang telah menyempurkan hukum Tuhan melalui pengorbanan-Nya dan telah mewujudkannya di dalam suatu Perjanjian yang Baru yang tidak lain adalah Perjanjian Kasih, dimana pembenaran dan keselamatan tersedia hanya oleh anugerah di dalam iman kepada Yesus Kristus sendiri. Bukan karena hasil usaha manusia , tetapi karena kasih Allah yang menganugerahkannya. 



\section{Bibliografi}

Baker, D. 2013, Mari Mengenal Perjanjian Lama, Jakarta: BPK Gunung Mulia.

Cyrellus, S 2008, Pendidik, Misionaris, Dan Motivator, Jakarta: BPK Gunung Mulia.

Fitriyana, N 2017, Spiritualitas Yesus, JIA/Juni 2017/Th. 18/Nomor 1 ISSN 2443-0919, 47-68.

Guthrie, D 2019, Teologi Perjanjian Baru II, Jakarta: BPK Gunung Mulia, 341.

Harefa, W 2014, Keunikan Kekristenan Berakar di Dalam Kesatuannya Dengan Kristus, KURIOUS: Jurnal Teologi dan Pendidikan Agama Kristen Vol. 2, No. 1, 32-45.

Keener, C 2015, Gift and Giver, Mengenali dan mengalami Kuasa Roh Kudus, Jakarta: Literatur Perkantas.

Kusnandar, Christie, 2017, Sepupuh Perintah Tuhan Bagian Kedua: Kasih Terhadap Manusia Dalam Tinjauan Etika Kristen, Jurnal Ilmiah Methonomi Vol. 3 No.2, 73-82.

Kiswara, C 1992, Dasar Firman Allah Makna dan Penerapannya, Yogyakarta: Kanisius.

Lee, W 2020, Hukum Taurat dan Anugerah Allah Dalam Ekonomi-Nya, Yayasan Perpustakaan Injil Indonesia,

Leon-Dufour, X 1990), Ensiklopedia Perjanjian Baru, Yogyakarta: Penerbit Kanisius.

Lina, Sri B.L. Simorangkir, 2020, Memahami Penerapan Taurat Pada Masa Yesus dan Implikasinya

Dalam Menghayati Firman Tuhan Pada Masa Kini, Jurnal Teologi Berita Hidup Vol. 2 No. 2, 16-32.

Nee, W 2020, Telah Mati Terhadap Hukum Taurat, Yayasan Perpustakaan Injil Indonesia.

Nee, W 2020, Hukum Taurat dan Anugerah Allah dalam EkonomiNya, Yayasan Perpustakaan Injil Indonesia.

Ong Thuan, Zaidan Imanuel, Memahami Konsep Penebusan Dalam Hukum Taurat dan Penggenapannya Dalam Diri Yesus Kristus, Jurnal STT Pelita Kebenaran Medan: Pondok Daud Dalam Teologi dan Pendidikan Agama Kristen Vol. 6 No.1

Park, A 2017, Imam Besar Kekal Yang Dijanjikan Dengan Sumpah, Depok: Yayasan Damai Sejahtera Utama.

Senduk, H 2014, Kristus Dalam Perjanjian Baru, Jakarta: Yayasan Bethel.

Senduk, H 2014, Pengetahuan Alkitab 1, Jakarta: Yayasan Bethel.

Senduk, H 2014, Pengetahuan Alkitab 2, Jakarta: Yayasan Bethel.

Wenham, J , Musa dan Pentateukh, Tafsiran Alkitab Masa Kini 1, Malang: Gandum Mas, t.th.

Wiersbe, W 2012, Loyal di Dalam Kristus, mengikuti Raja segala Raja, Bandung: Kalam Hidup. 